\title{
Electronic services in development a personal educational route
}

\section{Servicios electrónicos en la construcción de una ruta educativa personal}

\author{
Olga N. Soluyanova \\ https://orcid.org/0000-0003-4085-1347 \\ Moscow State University of Civil Engineering, Moscow, Russia. \\ Rustam I. Zapparov \\ rustam1981@yandex.ru \\ https://orcid.org/0000-0002-9302-9739 \\ Plekhanov Russian University of Economics, Moscow, Russia. \\ Galina G. Sechkareva \\ sechkareva@yandex.ru \\ https://orcid.org/0000-0002-3764-055X \\ Armavir State Pedagogical University, Armavir, Russia. \\ Nina A. Tkacheva \\ https://orcid.org/0000-0002-7545-6358 \\ Federal State Budget Educational Institution of Higher Education «Industrial University \\ of Tyumen», Tyumen, Russia. \\ Margarita I. Koldina \\ ritius@mail.ru \\ https://orcid.org/0000-0002-3368-7297 \\ Minin Nizhny Novgorod State Pedagogical University, Nizhny Novgorod, Russia.
}

Recibido: $27 / 08 / 21$

Aceptado: $7 / 11 / 21$

\begin{abstract}
The purpose of the article is the analysis of the experience of creating individual educational routes using electronic services. A survey was conducted among teachers of higher education institutions on the use of the most effective electronic services. The study involved teachers from 1 to 4 grades and the age range of 18 to 22 years. The results determinedq that electronic services play an important role in the creation of an individual educational path, expand the training opportunities of students and contribute to the development of skills and competencies that are important for a competitive specialist.
\end{abstract}


Keywords: electronic services, soft skills, personal educational path, electronic technologies, competencies.

\section{Resumen}

El propósito del artículo es el análisis de la experiencia de creación de rutas educativas individuales utilizando servicios electrónicos. Se realizó una encuesta entre docentes de instituciones de educación superior sobre el uso de los servicios electrónicos más efectivos. El estudio involucró a profesores de 1 a 4 cursos y el rango de edad de 18 a 22 años. Los resultados determinaronq que los servicios electrónicos juegan un papel importante en la creación de una ruta educativa individual, amplían las oportunidades de formación de los estudiantes y utilizan al desarrollo de habilidades y competencias que son importantes para un especialista competitivo.

Palabras clave: servicios electrónicos, habilidades blandas, ruta educativa personal, tecnologías electrónicas, competencias.

\section{Introduction}

With the development of scientific and technological progress, the processes of globalization and informatization, the primary need in the field of vocational education is to improve the quality of students' training, the development of professional competence, taking into account the needs of the modern labor market.

The demand for a specialist in the labor market is determined not only by his professional competencies, but also by soft, flexible universal skills (Kiseleva et al., 2019). The search for the most effective ways to form professional competencies and soft skills is one of the primary tasks solved in vocational education (Dobudko et al., 2019).

A personal educational route is a solution that allows, focusing on the needs, abilities and dispositions of the student, to prepare a highly qualified specialist (Smirnova et al., 2020).

Person-centered learning, popular for a long time, focusing on the individual needs of the student, remains relevant today (Aniskin et al., 2020). The most effective mastering of educational material and the development of competence through the construction of an individual educational route (Kharytonov et al., 2019).

An individual educational route allows the student to systematize their activities for the assigned tasks. Electronic services contribute to solving these problems (Shashlo et al., 2018).

The effectiveness of developing a personal educational route using electronic services depends on the timely monitoring of the educational process. 


\section{Theoretical framework}

An individual educational route is considered as an individual program of a student's educational activities, compiled on the basis of his interests and educational needs, which creates conditions for the disclosure of his abilities and the development of skills and competencies.

Regulations on an individual educational route are developed on the basis of the Federal Law "On Education in the Russian Federation" dated December 29, 2012 N 273-FZ, which guarantee the implementation of personal educational needs. (Law N 273-FZ, 2012)

The preparation of a student, including within the framework of an individual educational route, implies the development of soft skills, which occupy one of the most important places in the development of a modern competent specialist (Ivanova \& Korostelev, 2019). Therefore, we consider the development of soft skills as one of the indicators of the effectiveness of an individual educational route (Ponachugin \& Lapygin, 2019).

Soft skills are a tool to improve the competitiveness of a specialist in the labor market (Mazanyuk et al., 2020). The development of soft skills gives the student the opportunity to better adapt to professional activities (Demidov et al., 2020).

The development of a competent specialist with the necessary set of flexible skills is carried out using various electronic services.

Google is the most popular services both for the educational process in general and for development an individual educational route. This is a range of applications that make the educational process more lively and include a large number of students (Vaganova et al., 2019). Moreover, each student has the right to choose the most suitable tool for him (Klinkov, 2020).

Digital libraries provide access to a wide literature base on any topic of interest (Savka et al., 2020).

Interactive museums on online platforms allow virtual guided tours (Pinkovetskaia et al., 2020).

Electronic educational platforms include all the courses a student needs. The teacher can remotely enroll him in a specific course, and the student will have 24-hour access to it (Yarygin et al., 2019). The student solves problems, performs tests and watches the necessary lectures (Zulpukarova, 2019).

Zoom consults with the instructor. Each of the students asks the person of interest to him. The consultation is carried out both collectively and individually (Samerhanova, 2019). 
The service provides an opportunity for a student to work at the pace and mode in which it is convenient for him (Akvazba et al., 2019).

Despite the fact that e-mail has been around for a long time compared to other services, its popularity does not decrease (Bulaeva, et al., 2018). File sharing via email remains in demand. Here, both advisory assistance in solving individual issues and file exchange can be carried out (Shcerbakova \& Shcerbakova, 2019).

Time management applications have been actively used relatively recently (Vaganova et al., 2020). However, they are popular with students (Kidina, 2020). They allow you to focus on completing tasks, not to be distracted by phone calls and SMS messages (Pichugina et al., 2019). Teachers highlight this tool as one of the essential tools to maintain self-discipline in development a personal educational route (Vaganova et al., 2019).

Teachers also highlight the importance of cloud services, which allow storing large amounts of data and using them at any time for both students and teachers (Tsarapkina et al., 2021).

In electronic laboratories, in the absence of appropriate equipment or for organizing remote interaction to perform work, it is possible to create several unique tasks for the needs of each student (Nagovitsyn et al., 2020).

Kahoot and other services for creating educational projects, with the help of which tests, quizzes, educational games and marathons are created, expand the possibilities of individualizing the educational space (Rudenko \& Sarkisova, 2021). The student can take part in projects of interest to him.

\section{Methodology}

The paper presents a study on the process of development an individual educational route using electronic services.

A survey was conducted among teachers of higher educational institutions on the topic of the most effective, in their opinion, electronic services in the educational process in general and the construction of an individual educational route in particular. The article presents the most common answer options.

The level of development of soft skills within the framework of an individual educational route for students from 1 to 4 courses in the age range from 18 to 22 years was revealed.

The characteristics of the most common and demanded soft skills are revealed in the table. 
Table 1.

Characteristics of soft skills.

\begin{tabular}{ll}
\hline Skill & Characteristic \\
\hline Working in a team & $\begin{array}{l}\text { Maintaining connections to solve common problems, } \\
\text { making decisions to avoid conflicts, conducting } \\
\text { discussions, using electronic resources for remote } \\
\text { teamwork, sharing files }\end{array}$ \\
\hline Critical thinking & $\begin{array}{l}\text { Understanding the available in development, evaluating it } \\
\text { based on well-founded arguments, criteria, and using the } \\
\text { data obtained to resolve further issues }\end{array}$ \\
\hline Time management & $\begin{array}{l}\text { Organization of your own time to complete specific tasks, } \\
\text { compliance with deadlines, the degree of use of electronic } \\
\text { tools in organizing your own learning process }\end{array}$ \\
\hline Creativity & $\begin{array}{l}\text { Taking the initiative, making unconventional decisions, } \\
\text { generating new ideas, creatively solving problems, and } \\
\text { engaging new tools in your own activities to achieve better } \\
\text { results }\end{array}$ \\
\hline Flexible thinking & $\begin{array}{l}\text { Prompt response to emerging changes, resolution of } \\
\text { complex situations, thinking through several ideas, } \\
\text { unconventional thinking, readiness to use innovative tools } \\
\text { in solving current issues }\end{array}$ \\
\hline
\end{tabular}

Various electronic services were included in the construction of the routes.

The ability to apply soft skills was differentiated by level. The characteristics of the levels are presented in the table.

Table 2.

Characteristics of the levels of soft skills development in the process of development an individual educational route using electronic services.

\begin{tabular}{ll}
\hline Level & Characteristic \\
Creative & The student easily works in a team, shows leadership \\
& qualities. When development an individual educational \\
& route, it is included in the collective project \\
& activity. Actively uses electronic technologies to solve its \\
& tasks, achieving operational results. Responds quickly to \\
& changes that occur. Complies with deadlines. Solves \\
problems in several ways.
\end{tabular}


project activity. Responds to changes that occur. Tries to act within the established deadlines. If necessary, it can offer several options for solving problems.

Acceptable The student works in a team. When development an individual educational route, it is difficult for them to get involved in collective project activities. Applies electronic technologies. Responds to changes that occur. Sometimes it goes beyond the set deadlines. If necessary, it can offer several options for solving problems.

The development of soft skills is one of the most important factors reflecting the effectiveness of an individual educational route and electronic tools used for this.

\section{Results and discussion}

A survey was conducted among teachers to choose the most effective, in their opinion, electronic tools in development a personal educational route.

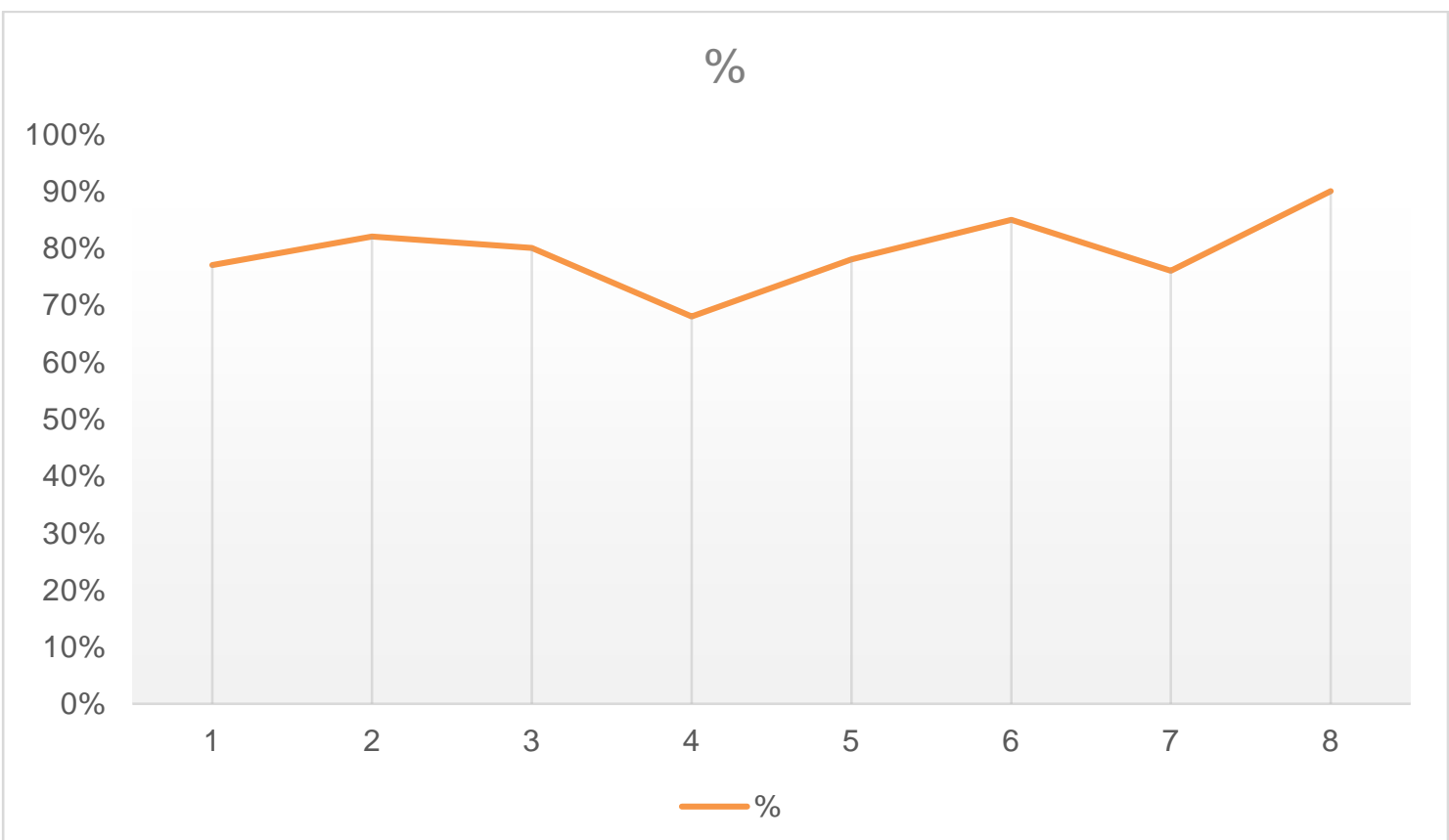

Fig. 1. Results of a survey of university teachers.

According to the results of the survey, the most demanded were:

1. Electronic educational platform;

2. Zoom;

3. Email;

4. Application time managers; 
5. Cloud storage;

6. Electronic laboratories;

7. Kahoot and services that allow you to create electronic quizzes and presentations;

8. Google services.

Each of the services presented is of great importance for students, since these tools are used by students both in learning and in everyday life. They communicate, carry out projects, solve problems creatively, that is, develop their flexible skills and are ready for further training.

Students of higher educational institutions also took part in the study. (6 groups of students). They were all categorized according to their age. In the learning process, teachers helped students to build an individual educational route using technical means.

The figure shows the results of checking the development of soft skills within the framework of an individual educational route.

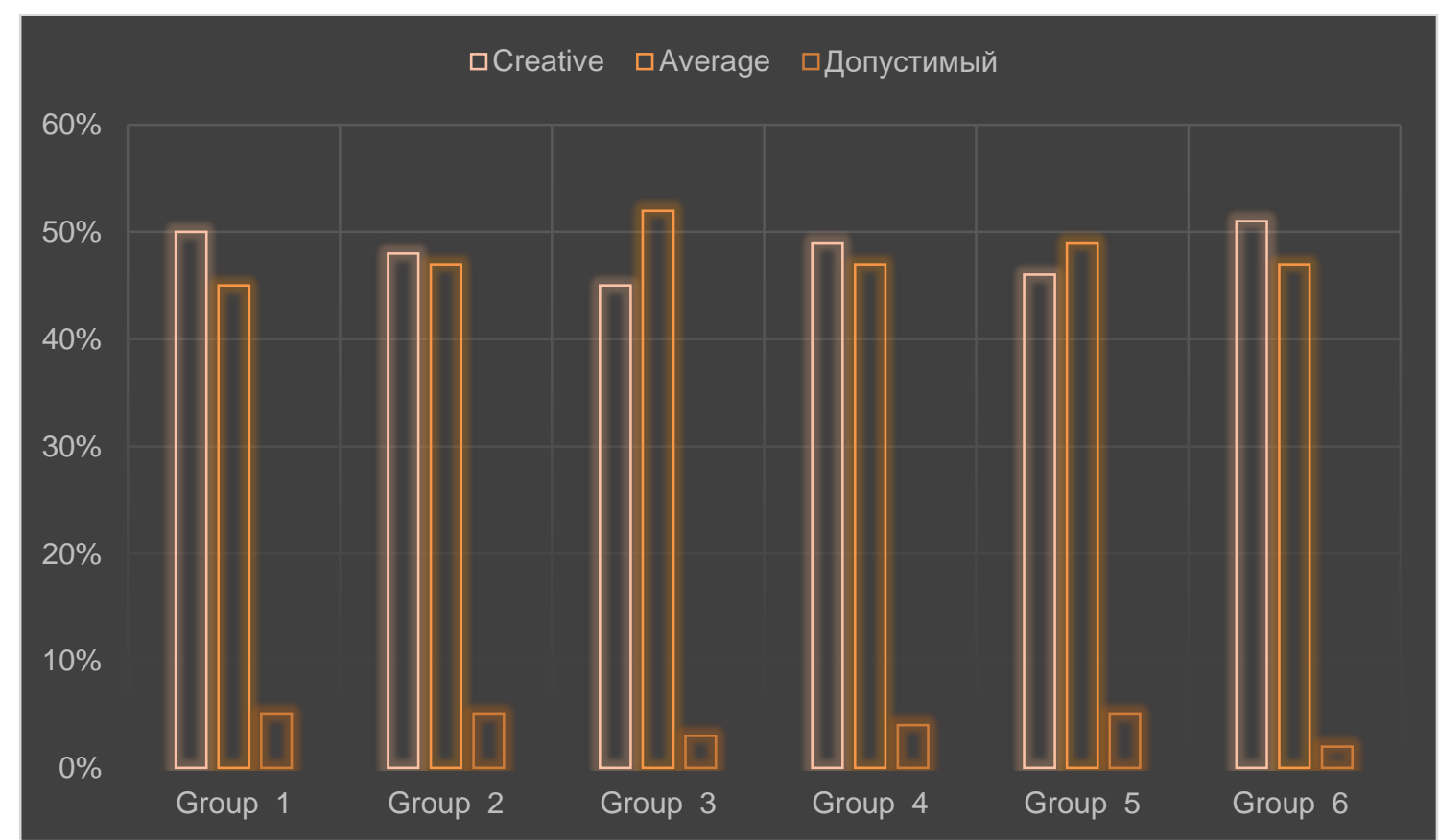

Fig. 2. The level of soft skills development within the individual educational route.

Each group of students who used electronic services in development an individual educational route in most cases has a creative and average level of soft skills development. Each of the students freely builds a dialogue with their fellow students, participates in projects, is able to critically assess the situation and is ready to creatively solve it. 


\section{Conclusions}

An analysis of the experience of development an individual educational route using electronic services has shown the high importance of electronic tools in the modern educational process. Based on the research data, in which we focused on the development of soft skills as significant elements of modern professional training, we can say that electronic services expand student opportunities. Students can quickly resolve issues remotely, creatively approach the solution of assigned tasks, critically assess the situation.

The development of soft skills shows that students are ready for further independent construction of the educational route. They are aware of their needs, determine the need to improve certain competencies.

The electronic services presented in the study have a wide range of tools that adapt to the needs of each student and contribute to the construction of an effective educational route.

\section{Bibliographic references}

Akvazba, E., Bogdanova, V., Uzlova, N., \& Patrusheva, I. (2019). Problems and prospects of the Russian indevelopment society. Amazonia Investiga, 8(20), 310-322. Retrieved

from https://amazoniainvestiga.info/index.php/amazonia/article/view/144.

Aniskin, V. N., Korostelev, A. A., Lvovna, B. A., Kurochkin, A. V., \& Sobakina, T. G. (2020). Teaching potential of integrated learning technologies Smart, Stem and Steam. Revista De La Universidad Del Zulia, 11(29), 328-336.

Bulaeva, M. N., Vaganova, O. I., Koldina, M. I., Lapshova, A. V., \& Khizhnyi, A.V. (2018). Preparation of Bachelors of Professional Training Using MOODLE. Advances in intelligent systems and computing, 622, pp. 406-411.

Dobudko, T.V., Korostelev, A.A., Gorbatov, S.V., Kurochkin, A.V., \& Akhmetov, L.G. (2019). The organization of the university educational process in terms of digitalization of education. Humanities and Social Sciences Reviews. 7(4), pp. 1148-1154.

Demidov, A., Syrina, T., \& Tretyakov, A. (2020). Development of Digital Skills and Media Education System: From the Organization of Environmental Education of Preschool Children to the ICT Competence of Teachers. Media Education (Mediaobrazovanie), 1, pp. 11-23. http://ejournal53.com/journals_n/1584456608.pdf

Ivanova, N., \& Korostelev, A. (2019). The impact of competitive approach on students' motivation in sport. Amazonia Investiga, 8(18), 483-490. Retrieved from https://amazoniainvestiga.info/index.php/amazonia/article/view/362

Kidina, I. M. (2020). Management of the pedagogical collective in the conditions of implementing distance learning. Baltic Humanitarian Journal. (Baltic Humanitarian Journal), Vol. 9 No 4 (33), pp. 93-96. 
Klinkov, G. T. (2020). The nature of pedagogical communication within the boundaries of systematic technological training. Scientific Vector of the Balkans, 4 (2 (8)), 11-13. URL: https://sci-vector-balkans.com/wp-content/uploads/2020/11/SVB-2020-T.428-2.pdf

Kharytonov, E., Kharytonova, O., Tolmachevska, Y., Fasii, B., \& Tkalych, M. (2019). Information Security and Means of Its Legal Support. Amazonia Investiga, 8(19), 255-265. Retrieved from https://amazoniainvestiga.info/index.php/amazonia/article/view/227

Kiseleva, O., Lebedev, A., Pinkovetskaia, I., Rojas-Bahamón, M., \& Arbeláez Campillo, D. (2019). Specialization and concentration of small and medium enterprises employees: Russian data. Amazonia Investiga, 8(20), 6-15. https://amazoniainvestiga.info/index.php/amazonia/article/view/59

Law N 273-FZ. "On Education in the Russian Federation". Date of the application: 26.09.2021 http://www.consultant.ru/document/cons_doc_LAW_140174/

Mazanyuk, E.F., Tretyakov, A.L., \& Amichba, L.R. (2020). Game technologies as a tool of motivation and improvement the quality of university students' training. SHS Web of Conferences: International Scientific and Practical Conference «Teacher Professionalism: Psychological and Pedagogical Support of a Successful Career» (ICTP 2020), Yalta, Russia, October 21-23, 2020. Vol. 87. 00108. https://www.shsconferences.org/articles/shsconf/abs/2020/15/shsconf_ictp2020_ 00108/shsconf_ictp2020_00108.html

Nagovitsyn, R. S., Vaganova, O. I., Kutepov, M. M., M. L. N., Kosenovich, O. V., Moeseev, Yu. V., Vorotova, M. S., \& Osipov, A. Y. (2020). Interactive Technologies in Developing Student's Motivation in Physical Education and Sport. International Journal of Applied Exercise Physiology, 9(6), 78-85.

Pichugina, G.A., \& Bondarchuk, A.I. (2019). Structure of the training case in the organization of the educational process. Humanitarian balkan research, 2(4), pp. 5-7.

Pinkovetskaia, I., Berezina, N., \& Sverdlikova, E. (2020). The main reasons for the exit of entrepreneurs from business. Amazonia Investiga, 9(26), 68-73. https://doi.org/10.34069/Al/2020.26.02.7

Pinkovetskaia, I., Kryukova, L., Arbeláez, D., \& Rojas-Bahamon, M. (2019). Female Entrepreneurship: Types of Economic. Activity. Tarih kultur ve sanat arastirmalari dergisi-journal of history culture and art research, 8(2), 253-265. DOI: 10.7596/taksad.v8i2.2153

Ponachugin, A.V., \& Lapygin, Yu.N. 2019. "Digital Educational Resources of the University: Design, Analysis and Expertise". In: Vestnik Mininskogo universiteta (Vestnik of Minin University), 7 (2), 5. (in Russ)

Rudenko, I. V., \& Sarkisova, I. V. (2021). Mentoring as a form of scientific and methodological support of the professional development of future teachers. Scientific Vector of the Balkans, 5. № 2(12).

Shashlo, N., Petruk, G., \& Korostelev, A. (2018). Determinants of integration interaction among the subjects of the entrepreneurial innovation ecosystem of macro region. 

Amazonia
Investiga,
$7(13)$,
351-363.

https://amazoniainvestiga.info/index.php/amazonia/article/view/569

Samerhanova, E.K. (2019). Development of competences in the field of mathematical modeling among teachers of vocational training in the conditions of the indevelopment and educational environment of the university. Vestnik of Minin University, 2 (27), p. 1-7. Available at: DOI: 10.26795/2307-1281-2019-7-2-4. Access: May 23, 2021.

Smirnova, Z.V., Vezetiu, E.V., Vaganova, O.I., Pluzhnikova, E.A., \& Akimova, I.V. (2020). Automated knowledge management through e-testing. International Journal of Advanced Trends in Computer Science and Engineering, 9(3), pp. 3256-3260.

Savka I. V., Yakymovych T. D., \& Yaremko, T. I. (2020). Modern principles of professional education of humanities cycles in higher education institutions, Scientific Vector of the Balkans, 3 (9), 25-29.URL: https://cyberleninka.ru/article/n/suchasni-printsipiprofesiynospryamovanogo-navchannya-distsiplin-gumanitarnogo-tsiklu-uzakladah-vischoyi-osviti

Shcerbakova, E.V., \& Shcerbakova, T. N. (2019). Experience of Use of Remote Computer Technologies at The Organization of Independent Work of Students in The Conditions of a Mark and rating system. Baltic Humanitarian Journal. (Baltic Humanitarian Journal), Vol. 8, No 4 (29), pp. 192-195.

Tsarapkina, J. M., Plahina, L. N., Konoplyuk, N. V., Vaganova, O. I., \& Lapshova, A. V. (2021). The development of bachelors' digital competencies at the university. Propositos y representaciones, 9, № SI, Article number e811.

Vaganova, O.I., Korostelev, A.A., Smirnova, Z.V., Abramova, N.S., \& Dolmatov, S.N. (2019). Improving teachers' professionalism through the development of creativity. International Journal of Innovative Technology and Exploring Engineering, 8(8), pp. 630-634.

Vaganova, O. I., Petrozitskaya, I. A., Snatovich, A. B., Odarich, I. N., \& Kirillova, I. K. (2020). Heuristic technologies of training in professional education. Amazonia Investiga, 9(27), 509-517. https://doi.org/10.34069/Al/2020.27.03.55

Yarygin, O.N., Korostelev, A.A., Akhmetov, L.G., \& Maseleno, A. (2019). Modeling of competence as a tool of goal setting for education in modern society. International Journal of Recent Technology and Engineering, 7(6), pp. 72-77.

Zulpukarova, D. I. (2019). Google applications in students self learning. Bulletin of Science and Practice, 5 (12), 420-430. URL: https://cyberleninka.ru/article/n/primenenie-google-prilozheniy-v-organizatsiisamostoyatelnoy-raboty-studentov 